\title{
Cushing Syndrome and Adrenocortical Carcinoma in a Patient With $\mathrm{CD}^{+}{ }^{+}$Lymphocytopenia
}

\author{
Stepben F. Lewis, MD, MS, Bennett S. Vogelman, MD, and
}

Frank $M$. Graziano, $M D, P b D$

In 1992, the Centers for Disease Control (CDC) defined idiopathic $\mathrm{CD}^{+}$lymphocytopenia as a syndrome of $\mathrm{CD}^{+}$cell counts less than $300 / \mu \mathrm{L}$ on more than one occasion in patients who are HIVseronegative and have no known immunodeficiency state. ${ }^{1}$ Numerous cases of idiopathic $\mathrm{CD}^{+}$lymphocytopenia have been reported and have been associated with a wide range of disease entities. ${ }^{2}$ We report here a case of idiopathic $\mathrm{CD}^{+}$lymphocytopenia in a patient who was later found to have Cushing syndrome caused by adrenal carcinoma.

\section{Case Report}

A 50-year-old gay man complained after a recent trip to Australia of severe back pain and peripheral edema. The back pain had developed several weeks earlier and was not associated with neurologic compromise or other systemic symptoms. The edema, which had developed gradually during the previous 12 months, was not associated with any other symptoms of renal, hepatic, cardiac, or thyroid dysfunction.

His medical history was pertinent for hypertension, geographic tongue, mild obesity, and sleep apnea requiring positive pressure ventilation.

One year before the onset of his symptoms, the patient's partner died of acquired immunodeficiency syndrome (AIDS). Because the patient had engaged in unprotected sex with his partner before knowing his partner was infected with the human immunodeficiency virus (HIV), the patient was tested for HIV infection but was seronegative. His $\mathrm{CD}^{+}$cell count, however, was $270 / \mu \mathrm{L}$ (normal $500-1300 / \mu \mathrm{L}$ ). An extensive evaluation for HIV infection, including enzyme immunoassays for

Submitted, revised 22 June 1999.

From the Department of Medicine, Section of General Internal Medicine (SFL), Section of Infectious Diseases (BSV), and Section of Rheumatology (FMG), University of Wisconsin School of Medicine, Madison. Address reprint requests to Frank M. Graziano, $\mathrm{MD}, \mathrm{PhD}$, University of Wisconsin Hospital and Clinics, Department of Medicine, H6/368 CSC, 600 Highland Ave., Madison, WI 53792.
HIV-1 and HIV-2, HIV-1 DNA by the polymerase chain reaction assay, HIV-1 peripheral blood lymphocyte culture, and p-24 antigen testing, was negative. These tests were repeated several months later and again were negative. The patient's condition was diagnosed as idiopathic CD4 ${ }^{+}$lymphocytopenia. During the next 6 months, his absolute $\mathrm{CD}^{+}$cell count declined to $160 / \mu \mathrm{L}$, and the patient was started on trimethoprim-sulfamethoxazole prophylaxis for Pneumocystis carinii infection.

When examined, the patient appeared cushingoid but was in no acute distress. His body habitus was centrally obese with upper and lower extremity wasting. His blood pressure was $150 / 95 \mathrm{~mm} \mathrm{Hg}$. A cutaneous examination found multiple ecchymotic lesions on the upper extremities and lower abdomen as well as a $1.5-\mathrm{cm}$ nodule with a necrotic center on the lateral aspect of his right arm. A head and neck examination was pertinent for facial plethora and a white coating on the lateral surfaces of his tongue. Findings of an examination of the heart and lungs were unremarkable. His abdomen was protuberant, his umbilicus was inverted, and he had diffuse dullness to percussion. The lower extremities showed moderate pitting edema to the knees bilaterally. A neurologic examination was nonfocal, but the patient had to be frequently refocused on his current problem by the evaluating physician.

Pertinent laboratory studies are shown in Table 1. Important findings include hyperglycemia, an elevated cortisol level that did not respond to dexamethasone, a markedly elevated urine free cortisol level, a low adrenocorticotrophin level, a low $\mathrm{CD}^{+}{ }^{+}$cell count with an reversed $\mathrm{CD}^{+}{ }^{+}$to $\mathrm{CD} 8^{+}$ ratio, and low immunoglobulin levels.

Thoracic and lumbar spine films showed severe osteopenia and multiple compression fractures of the thoracic and lumbar spine. Computed tomographs (CT) of the chest and abdomen showed a large adrenal mass and extensive lipomatosis. There were nodular lesions in the liver and right lower lobe of the lung. Biopsy of the lung lesion resulted in a diagnosis of metastatic adrenocortical 
Table 1. Patient Laboratory Findings.

\begin{tabular}{|c|c|c|}
\hline $\begin{array}{l}\text { Laboratory Tests and } \\
\text { Measurements }\end{array}$ & $\begin{array}{c}\text { At } \\
\text { Admission }\end{array}$ & $\begin{array}{l}\text { Normal } \\
\text { Range }\end{array}$ \\
\hline Hematocrit, \% & 38.0 & $40.0-50.0$ \\
\hline White cell count, $\times 10^{3} / \mu \mathrm{L}$ & 10.0 & $3.5-8.5$ \\
\hline \multicolumn{3}{|l|}{ Differential count, \% } \\
\hline Neutrophils & 77 & \\
\hline Lymphocytes & 8 & \\
\hline Monocytes & 1 & \\
\hline Metamyelocytes & 12 & \\
\hline Myelocytes & 1 & \\
\hline \multicolumn{3}{|l|}{ T cells, per $\mu \mathrm{L}$} \\
\hline Absolute $\mathrm{CD} 4^{+}$count & 140 & $500-1300$ \\
\hline Absolute $\mathrm{CD}^{+}$count & 630 & $210-690$ \\
\hline $\mathrm{CD}^{+}$to $\mathrm{CD}^{+}$ratio & 0.2 & $1.2-3.0$ \\
\hline \multicolumn{3}{|l|}{ Immunoglobulin levels, $\mathrm{mg} / \mathrm{dL}$} \\
\hline IgA & 117 & $68-378$ \\
\hline IgG & 464 & $694-1618$ \\
\hline $\operatorname{IgM}$ & 45 & $60-263$ \\
\hline Sodium, $\mathrm{mEq} / \mathrm{L}$ & 135 & $135-144$ \\
\hline Potassium, $\mathrm{mEq} / \mathrm{L}$ & 4.0 & $3.6-4.8$ \\
\hline Chloride, $\mathrm{mEq} / \mathrm{L}$ & 95 & $97-106$ \\
\hline Carbon dioxide, $\mathrm{mEq} / \mathrm{L}$ & 25 & $22-32$ \\
\hline Glucose, mg/dL & 266 & $70-110$ \\
\hline \multicolumn{3}{|l|}{ Cortisol, $\mu \mathrm{g} / \mathrm{dL}$} \\
\hline Before dexamethasone & 51.7 & \\
\hline After dexamethasone & 46.5 & \\
\hline Corticotropin, midnight, $\mathrm{pg} / \mathrm{mL}$ & $<0.1$ & $7-51$ \\
\hline Urinary free cortisol, $\mu g / 24 \mathrm{~h}$ & 1013 & $0-50$ \\
\hline
\end{tabular}

carcinoma. Biopsy of the skin nodule showed pleomorphic fungal elements that were identified as Exopbiala jeanselmei.

The patient underwent surgical debulking of the adrenal mass but died 5 months later as a result of complications of his metastatic disease. A postmortem examination was not performed.

\section{Discussion}

Marked reduction in the $\mathrm{CD}^{+}$lymphocyte count has been considered a marker of HIV infection. Since 1992, however, when the Centers for Disease Control and Prevention defined idiopathic CD4 ${ }^{+}$ lymphocytopenia, ${ }^{1}$ it has become clear that many patients have low $\mathrm{CD}^{+}$counts without $\mathrm{HIV}$ infection. We report the first case of idiopathic $\mathrm{CD}^{+}$lymphocytopenia associated with adrenocortical carcinoma and Cushing syndrome in a patient who had clear risk factors for HIV infection but no laboratory evidence of the disease.

The epidemiologic and clinical aspects of idiopathic $\mathrm{CD} 4^{+}$lymphocytopenia have now been ex- tensively described. Epidemiologic investigation of patients with idiopathic $\mathrm{CD}^{+}$lymphocytopenia has failed to show clustering of cases, spread to close contacts, or any evidence of a transmissible agent. ${ }^{2}$ Immunologic studies indicate that the syndrome differs from that seen with HIV infection in that all lymphocyte cell lines tend to decrease, and the lymphopenia is usually transient. ${ }^{3,4}$ In addition, immunoglobulin levels are normal or decreased in idiopathic $\mathrm{CD}^{+}$lymphocytopenia (as in our patient) but are usually increased with HIV infection. From a clinical standpoint, $40 \%$ of patients with reported idiopathic $\mathrm{CD}^{+}$lymphocytopenia have developed AIDS-defining illnesses, including cryptococcal meningitis, histoplasmosis, and Mycobacterium avium complex. ${ }^{2}$ The syndrome, however, has also been associated with many infectious entities not related to $\mathrm{AIDS}^{2}$ and with noninfectious diseases, such as autoimmune disorders, ${ }^{5}$ malnutrition, ${ }^{6}$ drugs, ${ }^{7}$ and skin disorders. ${ }^{8}$ Finally, a small subset of cases are asymptomatic, which raises the possibility that some persons are healthy but have had idiopathic $\mathrm{CD}^{+}$lymphocytopenia diagnosed through the recent increased screening for lymphocyte subsets. ${ }^{2,9}$ In summary, idiopathic $\mathrm{CD}^{+}$lymphocytopenia appears to represent a variety of disorders not related to HIV or any new transmissible agent but causing a generalized immunodeficiency state similar to that seen with HIV infection.

Approximately $20 \%$ of those patients with Cushing syndrome have adrenal tumors. Adrenocortical carcinoma is a rare tumor; only about 150 new cases are diagnosed each year in the United States, which is less than one case per million population and $0.02 \%$ of all invasive neoplasms. Adrenocortical carcinoma can occur at any age, but most patients are 30 to 60 years old when the diagnosis is made. The incidence among men and women is about equal, and the cause is unknown. An increased incidence among those infected with HIV has not been reported. Cushing syndrome has been associated with a number of infectious entities, including Nocardia, Pneumocystis, and Aspergillus organisms, and Cryptococcosis neoformans. ${ }^{10}$ Several cases of Alternaria infection, which is a pleomorphic fungus similar to the Exopbiala jeanselmei found in our patient, have been reported in Cushing syndrome. ${ }^{11,12}$ Our patient did not develop any infections other than the localized fungal infection of the skin. 
Relatively little has been reported regarding the immunologic aspects of Cushing syndrome. Reduction of total lymphocyte counts with the administration of exogenous glucocorticoids has been known for years and is believed to be due to redistribution of these cells to other body compartments. ${ }^{13}$ In addition to the quantitative decrease in lymphocytes, qualitative abnormalities in lymphocyte function have been reported. ${ }^{14}$ The effect of glucocorticoids on subtypes of $T$ lymphocytes has not been well established, ${ }^{15}$ however, and the selective decrease in $\mathrm{CD}^{+}$lymphocytes, which we found in this patient, has not been reported.

This case of Cushing syndrome associated with idiopathic $\mathrm{CD}^{+}$lymphocytopenia was confounded by several features. First, because the patient was gay and his partner died of AIDS, the low $\mathrm{CD}^{+}{ }^{+}$count was believed to be a marker for an immunodeficiency state related to the AIDS virus. In retrospect, our patient was developing the signs of Cushing syndrome about 1 year before he sought care for his symptoms. Our attention was drawn primarily to his immunologic status because of his personal history of exposure to HIV. Extensive testing (including DNA polymerase chain reaction and HIV culture) on two occasions ruled out HIV infection, however, and did not explain his $\mathrm{CD}^{+} \mathrm{T}$ cell lymphopenia. Second, Cushing syndrome has many of the infectious disease sequelae found with AIDS, making the correct diagnosis more elusive. Furthermore, several reports ${ }^{16,17}$ suggest that Cushing syndrome and AIDS might be immunologically linked, because many patients with AIDS have increased levels of cortisol, interleukin-1, and other cytokines, which can alter the hypothalamic-pituitary-adrenal axis. It is likely that our patient's low $\mathrm{CD}^{+}$count was due to the immunosuppressive effect of high cortisol levels associated with Cushing syndrome. With the relatively intense monitoring of lymphocyte subsets now taking place in many medical practices, it is important for the physician to know of idiopathic $\mathrm{CD}^{+}$lymphocytopenia and the spectrum of causes for this process.

\section{References}

1. Unexplained $\mathrm{CD} 4^{+} \mathrm{T}$-lymphocyte depletion in persons without evident HIV infection-United States. MMWR Morb Mortal W'ly Rep 1992;41:541-5.

2. Smith DK, Neal JJ, Holmberg SD. Unexplained opportunistic infections and $\mathrm{CD} 4^{+}$T-lymphocyto- penia without HIV infection. An investigation of cases in the United States. The Centers for Disease Control Idiopathic $\mathrm{CD}^{+} \mathrm{T}$-lymphocytopenia Task Force. N Engl J Med 1993;328:373-9.

3. Spira TJ, Jones BM, Nicholson JK, et al. Idiopathic $\mathrm{CD}^{+}{ }^{+} \mathrm{T}$-lymphocytopenia - an analysis of five patients with unexplained opportunistic infections. N Engl J Med 1993;328:386-92.

4. Duncan RA, von Reyn CF, Alliegro GM, et al. Idiopathic $\mathrm{CD}^{+}$T-lymphocytopenia - four patients with opportunistic infections and no evidence of HIV infection. N Engl J Med 1993;328:393-8.

5. Ammann A. T-cell immunodeficiency disorders. In: Fudenburg, HH, Stites DP, Terr A, editors. Basic and clinical immunology. 7th ed. Norwalk, Conn: Appleton \& Lange, 1991.

6. Kaiser FE, Morley JE. Idiopathic $\mathrm{CD}^{+}{ }^{+} \mathrm{T}-\mathrm{lym}-$ phopenia in older persons. J Am Geriatr Soc 1994; 42:1291-4.

7. Richert SM, Orchard JL. Bacterial esophagitis associated with $\mathrm{CD}^{+}{ }^{+} \mathrm{T}$-lymphocytopenia without HIV infection. Possible role of corticosteroid treatment. Dig Dis Sci 1995;40:183-5.

8. Ohashi DK, Crane JS, Spira TJ, Courrege ML. Idiopathic $\mathrm{CD}^{+}$T-cell lymphocytopenia with verrucae, basal cell carcinomas, and chronic tinea corporis infection. J Am Acad Dermatol 1994;31(5 Pt 2):889-91.

9. Busch MP, Valinsky JE, Paglierone T, et al. Screening of blood donors for idiopathic $\mathrm{CD} 4^{+} \mathrm{T}$-lymphocytopenia. Transfusion 1994;34:192-7.

10. Graham BS, Tucker WS Jr. Opportunistic infections in endogenous Cushing's syndrome. Ann Intern Med 1984;101:334-8.

11. Chen HC, Kao HF, Hsu ML, Lee JY. Cutaneous alternariosis in association with scabies or iatrogenic Cushing's syndrome. J Formos Med Assoc 1992;91: 462-6.

12. Guerin V, Barbaud A, Duquenne M, et al. Cushing's disease and cutaneous alternariosis. Arch Intern Med 1991;151:1865-8.

13. Fauci AS, Dale DC. The effect of hydrocortisone on the kinetics of normal human lymphocytes. Blood 1975;46:235-43.

14. Wurzburger MI, Prelevic GM, Brkic SD, Vuckovic S, Pendic B. Cushing's syndrome - transitory immune deficiency state? Postgrad Med J 1986;62:657-9.

15. Nelson AM, Conn DL. Series on pharmacology in practice. 9. Glucocorticoids in rheumatic disease. Mayo Clin Proc 1980;55:758-69.

16. Rossi R, Tommaselli AP, Panza N, et al. Hormonal and immunological pattern in a patient with acquired immunodeficiency syndrome related complex and Cushing's syndrome. J Endocrinol Invest 1992;15: 849-52.

17. Tauveron I, Thieblot $P$, Laurichesse $H$. The Cushing syndrome associated with AIDS. Ann Intern Med 1994;120:620-1. 